\title{
Farmers Perceptions of Dangers of Grazing on Farmland and Coping Strategies: Evidence from Ayamelum Local Government Area of Anambra State, Nigeria
}

\author{
Udemezue JC ${ }^{1 *}$, Ede $\mathrm{ON}^{1}$ and Udefi $\mathrm{IO}^{2}$ \\ ${ }^{1}$ National Root Crops Research Institute, Nigeria \\ + Nigerian Stored Product Research Institute, Nigeria
}

Submission: April 20, 2018; Published: June 12, 2018

*Corresponding author: Udemezue JC, National Root Crops Research Institute, Nigeria, Email: udemezuej@gmail.com

\begin{abstract}
This study examined farmers perceptions of the dangers of land use by Fulani herdsmen and coping strategies in Ayamelum Local Government Area of Anambra State, Nigeria. A total sample size of thirty two respondents were purposively selected for the study. Interview schedule was used for data collection and descriptive statistics such as frequency, mean and standard deviation were used in analyzing the data. The result shows that Loss of soil fertility with a weighted mean score 2.59 , environmental pollution with a weighted mean score 2.53 and crop failure with a weighted mean score 2.50 were identified as damages done by Fulani herdsmen. Similarly, use of fertilizer with a weighted mean score 2.81, occupational diversification with a weighted mean score (2.41), use of traditional rulers (2.38), use of physical fight (2.31) and early harvesting method (2.28) were used as coping strategies. This paper therefore recommended that; there is need to encourage education among two parties and this will bring a better perception for land use management. Farmers and herdsmen should be kept abreast with both principles of land use and management practices as to retain the fertility of the soil. Use of traditional rulers and local leaders should be well articulated in finding solution to land use management practices.
\end{abstract}

Keywords: Land use; Assessment; Implication for crop production

\section{Introduction}

Agriculture is the major economy of the people of Ayamelum local Government Area in Anambra State Nigeria, Even though there are other mineral resources available, agriculture dominates the main occupation of the area. Rain fall occurs seasonally with an average dry season, and this brings about the dynamics in the ecosystem between the Fulani herdsmen and farmers. The implications of this land use by Fulani herdsmen have brought about an incessant loss of soil fertilities. Land is probably the most important resources needed by man for his day to day existence. All human livelily hoods and activities directly depend on land at varying thresholds [1]. Builders, manufacturers, fishermen, miners, hunters and farmers, among others have different specifications for land for their productions/services. Among all users, agricultural production exhibits the highest form of sophistication in terms of land use [1]. Soil fertility is a limited factor to be considered in terms of land use principles and practices. Therefore, it is important to understand the extent of the damages done by the activities of Fulani herdsmen in the assessment of land use. The necessity to provide crops, animals and raw materials for industries in order to meet over growing demand has led to the high degrees of land use [2]. The competitions between these two agricultural land user groups (Fulani and Farmers) have sometimes turned into serious social friction. In Nigeria, production of arable crops is essentially the prominent feature of agricultural activities. Almost all farmers in Nigeria cultivate one or more arable crops for food and income. However, Nigerian agricultural production is dominated by rural-based small-scale arable crop producers, who account for about $80 \%$ of total food requirement $[3,4]$ revealed that the average farm size in arable crop production was 4.58ha. Moreso [5], indicated that 36.25 and 82.41 million hectares of arable crops were cultivated between 2004-2005 respectively. The most widely grown arable crop in Nigeria is maize which accounts for 6.6 and 7.5million hectares in 2004 and 2005 respectively [5]. Cattle herding is dominated almost entirely by Fulani tribe in Nigeria [6]. According to him, the optimum Fulani cattle herd size lies between 80 and 100, with a preponderance of female over male at ratio 4:1. Cattle belonging to individual members are usually herded together. Fulani men possessing less than twenty cows are considered to be poor, 
while women having six cow are seen as rich [6]. Women, however, controlled most of the small ruminants and all the poultries. Herding is dominated by the youths while decisions about grazing are made by the elderly family members. The Fulani herdsmen make excellent use of sign language, the cane and verbal command to drive the animals.

Herding season in Ayamelum Local Government Area begins from October to December which is the end of rainy season and the beginning of dry season. January to February is the harmattan season that is dominated by longer grazing hours, herd splitting and more frequent visit to stable water sources. The month of March and April are usually the toughest for herdsmen and cattle, because of the hottest period in the grazing calendar. May and June mark the end of dry season and vegetation begins to grow.

Fulbe began to settle on the plains of Bauchi Emirate transcending onto the grass land of the Jos [7]. Competitions between pastoralists and farmers have been in existence since the beginning of agriculture. The increase or decrease in its intensity and frequency depend on economy, environment and other factors. However, increases in the herd size due to improved conditions of the cattle, compelled the pastoralists to seek for more pasture above their limited range. Climate change has therefore constituted a great threat there by exacting enough pressure on the land, thus powering the competition between them. However, improvement on human health and population has also increased a much greater pressure on the land, thus bringing vast area of land into cultivation. Sequel to this, farmers and pastoralists have engaged in fierce struggle for access to such valuable lands, which more often than not, result in increased conflicts and violence.

Research has shown that $75 \%$ of our daily food comes from 12 arable crops and five animal species, with just three arable crops (rice, maize and wheat) accounting for about $60 \%$ of the calories and proteins obtained from plants [8]. Arable crops enjoy remarkable dominance and significant roles in the socio-economic lives of both rural and urban people. The antagonism between land users (herdsmen and farmers) has invariably caused food insecurity in the both urban and rural communities where arable crops dominated the activities of the farmers. According to [9], competition for land between and within various users groups has been a threat to mankind since time immemorial. None-Agricultural user group compete with agricultural user groups, thus making agricultural soil more intense to soil infertility. The competition between these two agricultural land user groups however, has caused an overt manifestation of crop failures to the majority of farmers in Nigeria. In spite of the incessant soil lost and crop failures generated by Fulani herdsmen, it appears that that there is a scarcity of information on the degrees of damages done by the Fulani herdsmen in the study area. In view of this, this research seeks to: Identify socio-economic characteristics of farmers, identify the degrees of damages on the soil, identify the coping strategies used by the farmers.

\section{Materials and Methods}

The study area for this research is Ayamelum Local Government Area. Ayamelum is a local government in Anambra State, Nigeria with her Headquarter at Anaku. The Local Government is of eight (8) communities. The communities are Omor, Omasi, Igbakwu, Anaku, Umumbo, Ifite Ogwurri, Umuerum and Umueje respectively. However, it is located at the left bank of Anambra River. It has a boundary with Uzouwani Local Government in Enugu State in the North, in the South with Anambra East local government, in the East with Awka North Local Government and in the West with Anambra West Local Government Anambra State. The estimated population of the local government in the last population census is 158, 152 [10]. Farming is the major occupation of Ayamelum people. In this study, eight (8) communities in Ayamelum were used based on their conflict perception. Four farmers each from a community were selected using random sampling techniques and this gave a total sample size of thirty two (32) respondents.

To determine the degree of damages on the soil, Three Point likert Type Scale was used. Farmers were asked to indicate the levels of damages on the soil fertility. Their response categories are; Very high=3, High=2, Not high=1. The values were added to have a value of 6 which when divided by 3 to get a mean score of 2. Variables with mean score less than 2 were regarded as "Not high" while variables with mean score equals or above 2 were regarded as "Very high. However, for the coping strategies used by the farmers, three point likert type scale was used. Farmers were asked to indicate their extent of usage on the listed variables. Their response categories were; always $=3$, sometime $=2$, not at all $=1$. Then the values were added to obtain a value of 6 which when divided by 3 to get a mean score of 2 . Variables with mean score less than 2.0 were regarded as "Not at all" while the variables with mean score equals or above 2.0 were regarded as "Always" used as a coping strategies for management of land use by the herdsmen. Data were collected through a structured interview schedule. Data collected for the research were analyzed using descriptive statistics such as frequency, percentage, mean score and standard deviation.

\section{Results and Discussion}

\section{Socio-economic characteristics}

Result in Table 1 shows that $59.4 \%$ of the respondents were male while $40.6 \%$ of the respondents were female. Moreso, $75 \%$ of the respondents were married while $6.3 \%$ of the respondents were single. Since the majority of the respondents were married, this could at the same time increase the release of family labour, thus making more hands available for agricultural production. The mean age was 41.31. This implies that young people of 
economic active age dominated the study area. This finding is in consonance with [1] who found that farmers in Taraba State were in their active productive age. The average mean household size of the respondents was 3.0 about $(75.0 \%)$ of the respondents were full time farmers while $1 \%$ of the respondents were into trading. Similarly, majority $(37.5 \%)$ of the respondents grow rice and cassava while $78.1 \%$ of the respondents acquired land on renting. Since majority of the respondents acquired land by renting, this could increase the cost incurred on farming. Also
$59.4 \%$ of the respondents cultivated $1-2$ ha while $71.9 \%$ of the respondents use hired labour as their source of labour. The average farm size cultivated by farmers was 1.8 ha. This shows that all the farmers in the local government were small-scale farmers. This finding is in line with [11] who reported that farmers in the south-east zone were small-scale farmers. About $65 \%$ of the respondents used input dealers/other farmers as the major source of agro input while $34.4 \%$ of the respondents used input dealers as their source of agro-input respectively.

Table 1: Percentage distribution of farmers according to socio-economic characteristics.

\begin{tabular}{|c|c|c|c|}
\hline Variables & Frequency & Percentage & Mean (M) \\
\hline \multicolumn{4}{|c|}{ Sex } \\
\hline Male & 19 & 59.4 & \\
\hline Female & 13 & 40.6 & \\
\hline \multicolumn{4}{|l|}{ Marital status } \\
\hline Single & 2 & 6.3 & \\
\hline Married & 24 & 75 & \\
\hline Widow & 2 & 6.3 & \\
\hline Divorce & 3 & 9.4 & \\
\hline Separated & 1 & 3.2 & \\
\hline \multicolumn{4}{|c|}{ Age } \\
\hline $21-30$ & 5 & 15.6 & \\
\hline $31-40$ & 12 & 37.5 & \\
\hline $41-50$ & 6 & 18.8 & 41.31 \\
\hline $51-60$ & 9 & 28.13 & \\
\hline \multicolumn{4}{|c|}{ Household Size } \\
\hline 01-Feb & 11 & 34.4 & \\
\hline 03-Apr & 15 & 46.9 & \\
\hline 05-Jun & 4 & 12.5 & 3 \\
\hline 07-Aug & 2 & 6.25 & \\
\hline \multicolumn{4}{|c|}{ Farm Size } \\
\hline$\leq 1 \mathrm{ha}$ & 7 & 21.9 & \\
\hline $1-2 \mathrm{ha}$ & 19 & 59.4 & 1.8 \\
\hline 3-4ha & 6 & 18.75 & \\
\hline \multicolumn{4}{|c|}{ Occupation } \\
\hline Full time farming & 24 & 75 & \\
\hline Trading & 1 & 3.1 & \\
\hline Civil servant & 7 & 21.9 & \\
\hline \multicolumn{4}{|c|}{ Crop Grown } \\
\hline Rice & 4 & 12.5 & \\
\hline Rice, cassava & 12 & 37.5 & \\
\hline Rice, cassava \& okro & 2 & 6.25 & \\
\hline Rice, cassava, okro \& maize & 9 & 28.13 & \\
\hline \multicolumn{4}{|c|}{ Rice, Cassava } \\
\hline Okro, maize \& yam & 2 & 6.25 & \\
\hline Rice, cassava \& yam & 1 & 3.131 & \\
\hline Cassava \& okoro & 2 & 6.25 & \\
\hline
\end{tabular}


Current Trends in Biomedical Engineering \& Biosciences

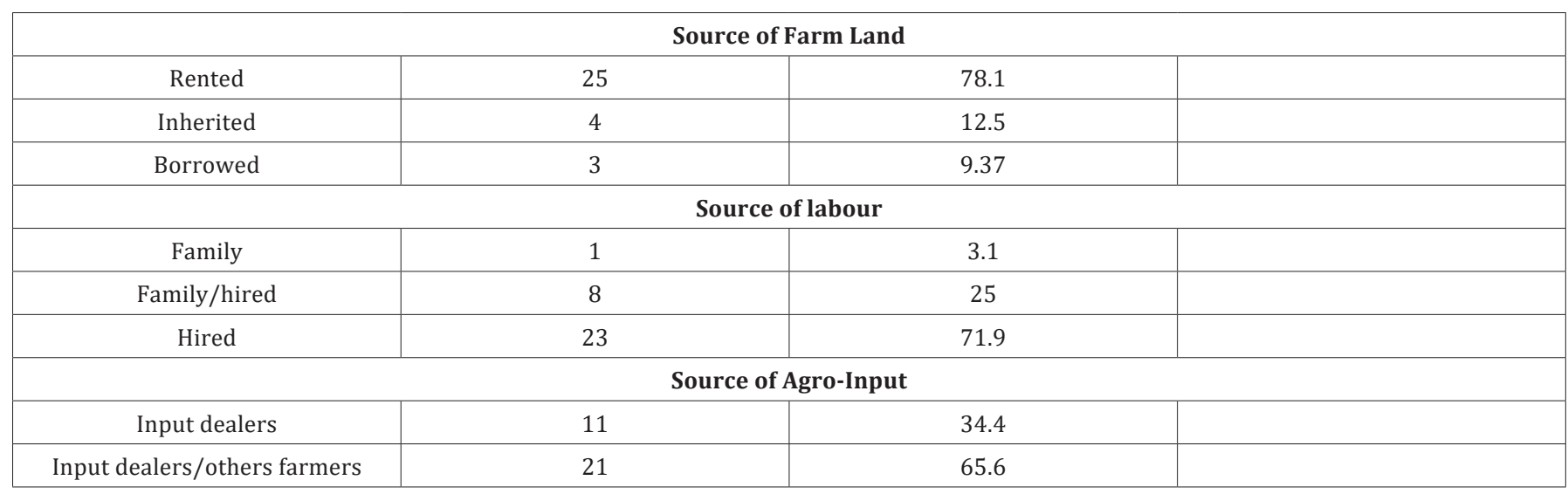

\section{Institutional characteristics}

Entry in Table 2 shows that majority (25.0\%) of the respondents completed primary school while $18.8 \%$ of the respondents completed secondary school. The high number of literate people among the farming population shows that the majority of them are in a better position to adopt a better coping strategies with regards to the damages done by Fulani herdsmen. The mean years of farming experiences were 16 years. This implies that farmers have had long period of farming experience, thus will increase their knowledge and experience on farming activities. About $84.4 \%$ of the respondents have access to credit while $15.6 \%$ of the respondents did not have access to credit. About $76.5 \%$ of the respondents sourced credit from micro-finance bank as either institutional source, while $80 \%$ of the respondents also sourced credit from Isusu club as their non-institutional source. $65.6 \%$ of the respondents have access to extensive service while $34.4 \%$ of the respondents also had no access to extension service respectively. Similarly, about $34.4 \%$ of the respondents applied 7-8bags of Fertilizer in the farm while $34.4 \%$ of the respondents also lost 2-3bags of crops in their farms as a result of the damages done by the Fulani herdsman.

Table 2: Percentage distribution of farmers according to institutional characteristics.

\begin{tabular}{|c|c|c|c|}
\hline Variables & Frequency & Percentage & Mean (M) \\
\hline Educational qualification & 1 & 3.1 & \\
\hline Non formal education & 4 & 12.5 & \\
\hline Primary school attempted & 8 & 25.3 & \\
\hline Primary school completed & 6 & 18.8 & \\
\hline Secondary school attempted & 6 & 18.8 & \\
\hline OND/NCE & 1 & 3.1 & \\
\hline First degree/HND & 4 & 12.5 & \\
\hline M.Sc/Ph.D & 2 & 6.3 & \\
\hline \multicolumn{4}{|c|}{ Farming Experience (years) } \\
\hline 01-Oct & 19 & 59.4 & \\
\hline Nov-20 & 3 & 9.4 & \\
\hline $21-30$ & 6 & 18.8 & 16 \\
\hline $31-40$ & 4 & 12.5 & \\
\hline \multicolumn{4}{|c|}{ Access to Credit } \\
\hline Yes & 27 & 84.4 & \\
\hline No & 5 & 15.6 & \\
\hline \multicolumn{4}{|c|}{ Institutional source (17) } \\
\hline Commercial bank & 1 & 5.9 & \\
\hline Agricultural bank & 3 & 17.6 & \\
\hline Microfinance bank & 13 & 76.5 & \\
\hline
\end{tabular}


Current Trends in Biomedical Engineering \& Biosciences

\begin{tabular}{|c|c|c|c|}
\hline \multicolumn{4}{|c|}{ Non Institutional Source (10) } \\
\hline Isusu clube & 8 & 80 & \\
\hline Money lender & 2 & 20 & \\
\hline \multicolumn{4}{|c|}{ Access to Extension Agent } \\
\hline Yes & 11 & 34.4 & \\
\hline No & 21 & 65.6 & \\
\hline \multicolumn{4}{|c|}{ Quantity of Fertilizer Use (kg) } \\
\hline $1-2(\mathrm{~kg})$ & 7 & 21.9 & \\
\hline $3-4(\mathrm{~kg})$ & 4 & 12.5 & \\
\hline $5-6(\mathrm{~kg})$ & 4 & 12.5 & \\
\hline $7-8(\mathrm{~kg})$ & 11 & 34.4 & \\
\hline $9-10(\mathrm{~kg})$ & 6 & 18.8 & \\
\hline \multicolumn{4}{|c|}{ Estimated Lost (kg) } \\
\hline $0-1$ bags & 2 & 6.3 & \\
\hline 2-3 bags & 11 & 34.4 & \\
\hline 4-5 bags & 8 & 25 & \\
\hline 6-7 bags & 3 & 9.4 & 5.06 \\
\hline 8-9bags & 2 & 6.3 & \\
\hline 10-11 bags & 6 & 18.8 & \\
\hline
\end{tabular}

Figures in Table 3 indicate the degree of damages done by Fulani herdsmen in the study area. The degrees of damages were categorized into very high, high and not high and later ranked in descending order of the perceived damages. Loss of soil fertility was ranked first with a weighted mean score 2.59 , environmental pollution was ranked second with a weighted mean score 2.53 and crop failure was also ranked third with a weighted mean score 2.50. Erosion (1.47), chemical deterioration (1.25), loss of land (1.09) and addition of nutrient (1.00) were also perceived as damages done by Fulani herdsmen activities.

Table 3: Degree of damages done by fulani herdsmen.

\begin{tabular}{|c|c|c|}
\hline Variables & Mean & Std. Deviation \\
\hline Loss of soil fertility & 2.59 & 0.126 \\
\hline Environmental pollution & 2.53 & 0.11 \\
\hline Crop failure & 2.5 & 0.9 \\
\hline Erosion & 1.47 & 0.1 \\
\hline Chemical deterioration & 1.25 & 0.069 \\
\hline Loss of land & 1.09 & 0 \\
\hline Addition of nutrient to soil & 1 & 0.78 \\
\hline
\end{tabular}

Figures in Table 4 also indicate the coping strategies for land use by Fulani herdsmen in the study area. The coping strategies were grouped into always, sometime and not at all respectively. Use of fertilizer with a weighted mean score 2-81, occupational diversification with a weighted mean score 2.41 , use of traditional rulers with a weighted mean score 2.38, use of physical fight with a weighted mean score 2.31 and use of early harvesting method with a weighted mean score 2.28 as their best option for managing the damages done by the Fulani herdsmen in the study area. Other coping strategies were; use of soil treatment (1.09), use of policemen (1.06), change of farm land (1.00) and use of fence (1.00) therein. In the light of the above, this finding, therefore disagreed with Rashid (2012) who found that the most commonly used coping strategies by farmers in Kwara State was seeking help from friends and relations. In the same vein, the standard deviation values were less than one in all the variables. This implies that the responses of the respondents on these variables did not vary much from the mean, thus, can be useful in policy formulation. 
: Coping strategies used by farmers.

\begin{tabular}{|c|c|c|}
\hline Variables & Mean & Std. Deviation \\
\hline Use of fertilizer & 2.81 & 0.95 \\
\hline Occupational diversification & 2.41 & 0.134 \\
\hline Use of traditional ruler to ban them from encroachment & 2.38 & 0.125 \\
\hline Use of physical fight by farmers to drive them out of their farm & 2.31 & 0.152 \\
\hline Use of early harvesting method & 2.28 & 0.129 \\
\hline Changing of time of planting & 1.59 & 0.118 \\
\hline Use of soil treatment & 1.09 & 0.52 \\
\hline Use of policemen & 1.06 & 0.062 \\
\hline Change of farmland & 1 & 0 \\
\hline Use of fence & 1 & 0 \\
\hline
\end{tabular}

\section{Conclusion and Recommendation}

The periodic struggle between farmers and Fulani herdsmen over a limited land has resulted into conflicts. These conflicts have seriously become more problematic and destructive since Fulani herdsmen do not possess the right to land, they therefore, rely heavily on open and cultivated land to feed their cows and cattle. The implications have automatically caused a lot of land damages and in the same vain compelled farmers to apply more fertilizers on their farm in order to recover the fertility of the land. However, farmers affected in the study area have used application of fertilizer, occupational diversification, traditional rulers, physical fight and use of early harvesting method as coping strategies for land use management. In order to put the problems to an end, both groups (farmer-herdsmen) should adopt realistic coping strategies and in co operate them into the mainstream activities of farmer-herdsmen management. With respect to the above, the following recommendations were made; Government at all levels should integrate efforts to make fertilizer available to farmers as to reduce the cost incurred on fertilizer application. There is need to encourage education among two parties and this will bring a better perception for land use management. Farmers and herdsmen should be kept abreast with both principles of land use and management practices as to retain the fertility of the soil. Use of traditional rulers and local leaders should be well articulated in finding solution to land use management practices.

\section{References}

1. Rashid SA (2012) Land use conflict between farmers and herdsmenimplications for agricultural and rural development, Nigeria.
2. Nyong A, Fiki C (2009) Droughts - related conflicts, management and resolution in the west African Sahel. Human security and climate change international workshop. Oslo; GECHS, CICERO and PR20.

3. Fayinka FA (2004) Food security in Nigeria: challenges under democratic dispensation. 19th ARMT Annual Lecture, Nigeria.

4. Alhassan U (2013) Herdsmen and farmers conflicts in north-eastern Nigeria: causes, repercussions and resolutions. Academic Journal of Interdisciplinary Studies 2(5).

5. Central Bank of Nigeria, CBN (2005) Annual Reports and Statement of Accounts. Abuja, Nigeria.

6. Iro I (1994) The fulani herding system washington. African Development Foundation, US.

7. Blench R (2010) Conflict between pastoralists and cultivators in nigeria. Kay Williamson Educational Foundation Cambridge, UK.

8. Lambrou Y, Laub R (2006) Gender local knowledge and lessons learnt in documenting and conserving agro biodiversity. UNU- WIDER Research Paper No. 2006/69.

9. Gefu J0, Kolawole A (2002) Conflict in common property resource use: experiences from an irrigation project. Paper Prepared For 9th Conference of The International Association For The Study of Common Property.

10. National Population Commission (NPC) (2006) Population figure. Federal Republic of Nigeria, Abuja, Nigeria.

11. Mbanaso EO (2010) Adoption and disadoption of sweet potato production and processing technologies by farmers in south-eastern nigeria. Department of Agricultural Extension, University of Nigeria, Nsukka, Nigeria, pp. 20-116. 
This work is licensed under Creative Commons Attribution 4.0 License DOI: 10.19080/CTBEB.2018.15.555914
Your next submission with Juniper Publishers will reach you the below assets

- Quality Editorial service

- Swift Peer Review

- Reprints availability

- E-prints Service

- Manuscript Podcast for convenient understanding

- Global attainment for your research

- Manuscript accessibility in different formats

( Pdf, E-pub, Full Text, Audio)

- Unceasing customer service

Track the below URL for one-step submission https://juniperpublishers.com/online-submission.php 